in the written and spoken word. To attain these purposes the processes of democracy must be much improved.

In thus foreshadowing in general terms the process of future growth in the democratic idea, Mr. Roosevelt was contemplating democracy as of the spirit, as a way of life and not merely as a political system, contrasting it with another 'New Order' of which much has been heard recently. Of the methods of this latter no graver indictment could be set forth than in the preamble to the proposed post-War agreement of co-operation between Poland and Czechoslovakia, in which it is shown that among its other crimes the Nazi regime is exterminating the intellectual class and all manifestations of cultural life, while despoiling these countries of their treasures of art and science and persecuting all religious beliefs. Against the spirit of these and other Nazi crimes "unparalleled in all human history", the agreement between Poland and Czechoslovakia aims at setting up an association "which would become a new order in Central Europe and a guarantee of its stability", no less than the 'New Order' of the President of the United States, based upon "respect for the freedom of nations, the principles of democracy and the dignity of man".

\section{Photographic Exhibitions of Indian Art and Religion}

THE exhibition of photographs illustrating Indian art and religion at the Imperial Institute, South Kensington, London, which was opened by Mr. L. S. Amery, H.M. Secretary of State for India, on November 13, will repay careful study. It does, in fact, convey a clearer view of Indian genius and mentality than many collections of a more spectacular and imposing character. As Mr. Amery pointed out in declaring the exhibition open, just as Europe in the Middle Ages had embodied its ideas and ideals in the cathedral, so in India Hinduism had attained the highest artistic expression of its religious conceptions in the temple; and ornamentation and decoration were the natural media in which both the artistic and the mental perceptions of India were illustrated. In order to understand India, Mr. Amery went on to say, it is necessary to have a perception of her architecture, her sculpture and her temple symbolism. The selection and grouping of the photographs in this exhibition, as well as the carefully prepared captions, are such as to give the visitor who examines them with attention, even if his previous knowledge of Indian art be slight, something more than a superficial view of the three aspects of Indian culture to which Mr. Amery referred; moreover, he will be impressed by the subtlety which pervades all Indian religious art, whether Hindu, Buddhist or Jain, and makes it in virtue of its all-pervading symbolism so remarkable a vehicle for conveying theological and philosophical concepts and ideas.

The arrangements for the exhibition have been made by the India Society and the Warburg Institute. The photographs, which attain a high standard of technical skill, are the work of Dr. Stella Kramritsch, lecturer on Indian art in the University of Calcutta. They illustrate developments in Hindu temple architecture and religious art, inclusive of such reform movements as Buddhism and Jainism from 200 B.c. to A.D. 1700. Broadly speaking, the arrangement is chronological ; but since, as already indicated, interest centres upon religious coneepts rather than æsthetic principles and achievement, though the latter are by no means passed over, examples are grouped and classified to illustrate these concepts. Naturally, in the early phases the Indianization of classical Greek art in Northern India figures prominently, while the group covering the setting of the temple demonstrates characteristic examples of the geographical environment as well as external form. Attention may be directed in particular, however, to the illustrations of the growth and meaning of symbolism, as well as of the worship of the symbol, and its plan in Indian religion and philosophy, the most striking example of this to the Western mode of thought being the manner in which the rhythms of the body as in dancing, or its functions as in sexual relations, are made to express a state of mind on a cosmic principle.

\section{Antiseptics in War-Time Surgery}

THE winter session of the Pharmaceutical Society's evening meetings was inaugurated on November 14 by Prof. A. Fleming, professor of bacteriology in the University of London, who delivered a lecture on "Antiseptics in War-Time Surgery". He said that in the present War surgeons should be able to undertake their work more efficiently than they were in 1914 in view of the chemical antiseptics which are now available but were then lacking. Thus the present situation in respect of the treatment of war wounds is infinitely more satisfactory than it was in the War of 1914-18. The antiseptics in use in 1914 have since been shown to be of little value for use in war-time surgery. Carbolic acid, for example, is effective when used otherwise than in connexion with the human body, but inside the body its lack of value is shown by the diminution of its efficiency with increasing concentrations, this being due to its action in destroying the leucocytes. Consequently carbolic acid is not of any great use as an antiseptic in the treatment of wounds.

Prof. Fleming also pointed out that the dyes are of little value as they are absorbed by the cotton wool used in dressing the wounds. Regarding antiseptics belonging to the sulphonamide group, he gave a warning against placing too much faith in them. They are not, he said, general antiseptics but are specific to certain bacteria; further, the action of these antiseptics is neutralized by chemicals, pus and dead bacteria and they are therefore of little value in the treatment of seriously septic wounds, in which pus and bacteria were inevitably present. The virtue of this new group of antiseptics is in their high solubility; they dissolve to form high concentrations in the wound. The sulphonamides are of great value in the treatment of fresh wounds where pus and bacteria are absent, since they inhibit the growth of certain important bacteria, and there is nothing in the fresh wound to inhibit the action of the sulphonamide. 